\title{
Intracardiac tumor as a rare manifestation of genetic syndromes-presentation of a family with Gorlin syndrome and a literature review
}

\author{
Krzysztof Szczałuba $^{1}$ (D) Ewa Makuła ${ }^{2} \cdot$ Anna Piórecka-Makuła $^{3}$ (D) Justyna Sicińska ${ }^{4}$ (D) Małgorzata Rydzanicz ${ }^{1}$ (D) \\ Piotr Gasperowicz ${ }^{1} \cdot$ Rafał Płoski $^{1}$ (D) $\cdot$ Bożena Werner ${ }^{3}$ (D)
}

Received: 3 July 2020 / Revised: 19 August 2020 / Accepted: 6 September 2020 / Published online: 22 September 2020

(C) The Author(s) 2020

\begin{abstract}
Intracardiac tumors in children are relatively rare, but their clinical consequences may include severe outflow tract obstruction, embolism, cardiac insufficiency, or rhythm disturbances. In some cases, the tumor may constitute part of a genetic condition and prompt additional investigations, as well as a modification of therapeutic management. Herein, we present a molecularly confirmed familial case of Gorlin syndrome with an early cardiac tumor as a presenting sign. We provide detailed clinical characteristics of the affected individuals and a useful review of syndromic causes of pediatric cardiac tumors in clinical practice.
\end{abstract}

Keywords Cardiac tumor $\cdot$ Fibroma $\cdot$ Gorlin syndrome $\cdot$ Familial $\cdot$ Exome sequencing

\section{Introduction}

Cardiac tumors are benign or malignant neoplasms that may originate in all the three layers of heart tissue (Uzun et al. 2007). Their frequency in fetal life is estimated at $0.14 \%$, while postnatal population prevalence reaches $0.5 \%$ in cases of children evaluated for cardiac symptoms (Uzun et al. 2007; Beghetti et al. 1997; Linnemeier et al. 2015). About $90 \%$ of the primary cardiac neoplasms have benign characteristics. The most common type is rhabdomyoma (up to 60\%) followed by teratoma, fibroma, and myxoma (Holley et al. 1995, Uzun et al. 2007; Tzani et al. 2017). In the majority of patients, intracardiac tumors are isolated findings on fetal or infantile

Communicated by: Michal Witt

Rafał Płoski

rploski@wp.pl

1 Department of Medical Genetics, Medical University of Warsaw, ul Pawinskiego 3c, 02-106 Warsaw, Poland

2 Medical University of Warsaw, Warsaw, Poland

3 Department of Pediatric Cardiology and General Pediatrics, Medical University of Warsaw, Warsaw, Poland

4 Clinical Department of Dermatology, Central Clinical Hospital of the MSWiA, Warsaw, Poland echocardiogram, while in the rest, they are part of a genetic syndrome diagnosis (Vidaillet 1988).

Robert Gorlin estimated that in his series, close to $4 \%$ of all cardiac fibromas were part of nevoid basal cell carcinoma syndrome (NBCCS, Gorlin syndrome) (OMIM:109400) (Gorlin 1987). NBCCS is characterized by lamellar or early calcification of the falx, jaw keratocysts, palmar and/or plantar pits, and multiple and/or early-onset basal cell carcinomas (Gorlin 2004; Bree et al. 2011). Early diagnosis of the syndrome enables optimal personalized care. Majority of Gorlin syndrome cases are caused by mutations in PTCH1 (Patched1) gene, which is part of the Hedgehog (Hh) molecular pathway (Johnson et al. 1996).

Herein, we show a molecularly confirmed familial case of Gorlin syndrome consisting of an infant proband presenting with intracardiac tumor, polydactyly, and macrocephaly and the father with features of macrocephaly, mitten-type syndactyly of fingers, polydactyly, and maxillary cysts. We describe current and future targeted treatment options in our familial case and provide a review of syndromic causes of pediatric intracardiac tumors.

\section{Family report}

We present a case of an infant girl with multiple dysmorphic features and a cardiac tumor of unknown origin diagnosed 
postnatally. The girl was born preterm at 36 weeks' gestational age with the birth weight of $4000 \mathrm{~g}$ by caesarean section due to maternal hypertension. The Apgar score was 3 and 5 at 1 and $5 \mathrm{~min}$ after birth, respectively. After initial resuscitation, the transthoracic echocardiography was performed revealing a tumor in the left ventricle. The neonate was referred to the department of pediatric cardiology for subsequent diagnostics.

On admission, the child was in a serious but stable condition with normal resting heart rate of 150 beats per minute (bpm) and arterial blood pressure of $81 / 68 \mathrm{mmHg}$. Blood oxygen saturation was $92-94 \%$, and capillary refill time was normal. Macrocephaly with head circumference of $38.5 \mathrm{~cm}$ ( $>97$ th centile), bilateral polydactyly of fingers with unilateral polydactyly of toes, and a natal tooth on lower gingiva were observed (Fig. 1a). Dyspnea signs were present with retractions of lower intercostal spaces and tachypnea $(70 / \mathrm{min})$. Heart auscultation revealed systolic murmur graded $2 / 6$ on Levine scale heard over the whole heart. The liver edge was palpable $1.5 \mathrm{~cm}$ below the costal margin. The remaining physical examination was unremarkable.

Laboratory testing revealed anaemias (hemoglobin concentration of $10.8 \mathrm{~g} / \mathrm{dL}$ ) and significantly increased NTproBNP level $(26,500 \mathrm{pg} / \mathrm{ml})$ (the upper norm for NTproBNP at $598 \mathrm{pg} / \mathrm{ml}$ was established by Lin et al. 2013). Tumor lysis laboratory markers (uric acid, potassium, lactate dehydrogenase) were within the normal limits. The 12lead electrocardiogram (ECG) showed sinus rhythm with delayed intraventricular conduction and generalized repolarization abnormalities - inverted $\mathrm{T}$ waves in leads II, III, aVF, V4-V6, and low-amplitude T waves in leads I and aVL (Fig. 1b). The anteroposterior chest radiograph was suggestive of cardiomegaly with cardiothoracic ratio of around 0.7 (Fig. 1c).

Two-dimensional transthoracic echocardiography revealed a large bean-shaped tumor (size, $50 \times 30 \mathrm{~mm}$ ) attached to the posterolateral wall of left ventricle with the areas of hyper- and hypodensity (Fig. 1d). Moderate pericardial effusion with late diastolic compression of the right atrium was found. Patent ductus arteriosus (PDA) with diameter of $3.5 \mathrm{~mm}$ with left-toright shunt coexisted with dilation of the pulmonary trunk and pulmonary arteries.

Cardiac magnetic resonance confirmed echocardiographical findings and revealed possible diaphragm and parietal pericardium invasion. Contractility of left ventricle wall was impaired by presence of the tumor mass. Peripheral contrast enhancement suggested the presence of tumor capsule, and the lack of central enhancement suggested necrosis. Additionally, oval mass (size, $16 \times 10 \mathrm{~mm}$ ) localized between the anterior and lateral wall of left ventricle with peripheral contrast enhancement similar to the main tumor was described; however, the connection between them could not be excluded. Imaging studies suggested rhabdomyoma, fibroma, or sarcoma.
Subsequent treatment included administration of spironolactone, furosemide, and captopril. Hemodynamically significant PDA was closed with PDA occluder. Signs of dyspnea decreased. Because of the high risk of thromboembolic events, cardiac tamponade, arrhythmia, and possible presence of metastases, the biopsy during the procedure was not performed.

Magnetic resonance imaging of central nervous system showed no tumors. Rhabdomyoma associated with tuberous sclerosis could still not be excluded; thus, therapy with sirolimus was started. After 4 weeks, no significant changes in tumor size were observed, and sirolimus therapy was discontinued. Pericardial drainage due to fluid accumulation was performed. Subsequent specimen cytology was negative for tumor cells.

Additionally, wide QRS extra beats were observed during hospitalization in the standard ECG monitoring. Twenty-fourhour Holter monitoring revealed a few episodes of ventricular tachycardia up to $200 \mathrm{bpm}$. Metoprolol was administered, and during subsequent tests, only single premature ventricular beats were observed. Pending genetic test results the infant was discharged in a good general condition.

The 29-year-old father of the proband girl presented with macrocephaly (head circumference $61 \mathrm{~cm},>97$ th centile) and frontal bossing, mitten-hand-type bilateral syndactyly, and unilateral postaxial hand polydactyly (Fig. 1e). He had a history of maxillary cyst surgery at age 22 (Fig. 1f). He had no other medical issues and otherwise was normal physically and intellectually.

\section{Genomic testing}

In the proband, exome sequencing (ES) was performed using Nextera Flex for Enrichment sample preparation kit combined with TruSeq DNA Exome (45 Mb) probes (Illumina, San Diego, CA, USA) according to the manufacturer's instruction. Library was pair-end sequenced $(2 \times 100 \mathrm{bp})$ on HiSeq 1500 (Illumina) to the mean depth $83 \times, 98.7 \%$ of target was covered $\geq 10 \times$, and $94.4 \%$ was covered $\geq 20 \times$. Bioinformatics analysis of raw ES data and variant prioritization were performed as previously described (Rydzanicz et al. 2019). Selected variants were further validated in the proband, her parents, and grandparents (father's parents) by amplicon deep sequencing (ADS) performed using Nextera XT Kit (Illumina) and sequenced on HiSeq 1500 (Illumina).

Considering the patient's phenotype and the characteristics of the variants, we prioritized four ultrarare variants in $A S H 1 L$, $C D K N 2 A, S I X 4$, and $P T C H 1$ genes for verification and family study. Variants in ASH1L, CDKN2A, and SIX4 were inherited from the healthy mother, while the variant in the $P T C H 1$ gene (hg38; g.chr9:095459719-A>G, NM_000264.5:c.2768T>C, p.(Leu923Pro)) was inherited from the affected father. The p.(Leu923Pro) variant in PTCH1 was absent from the 

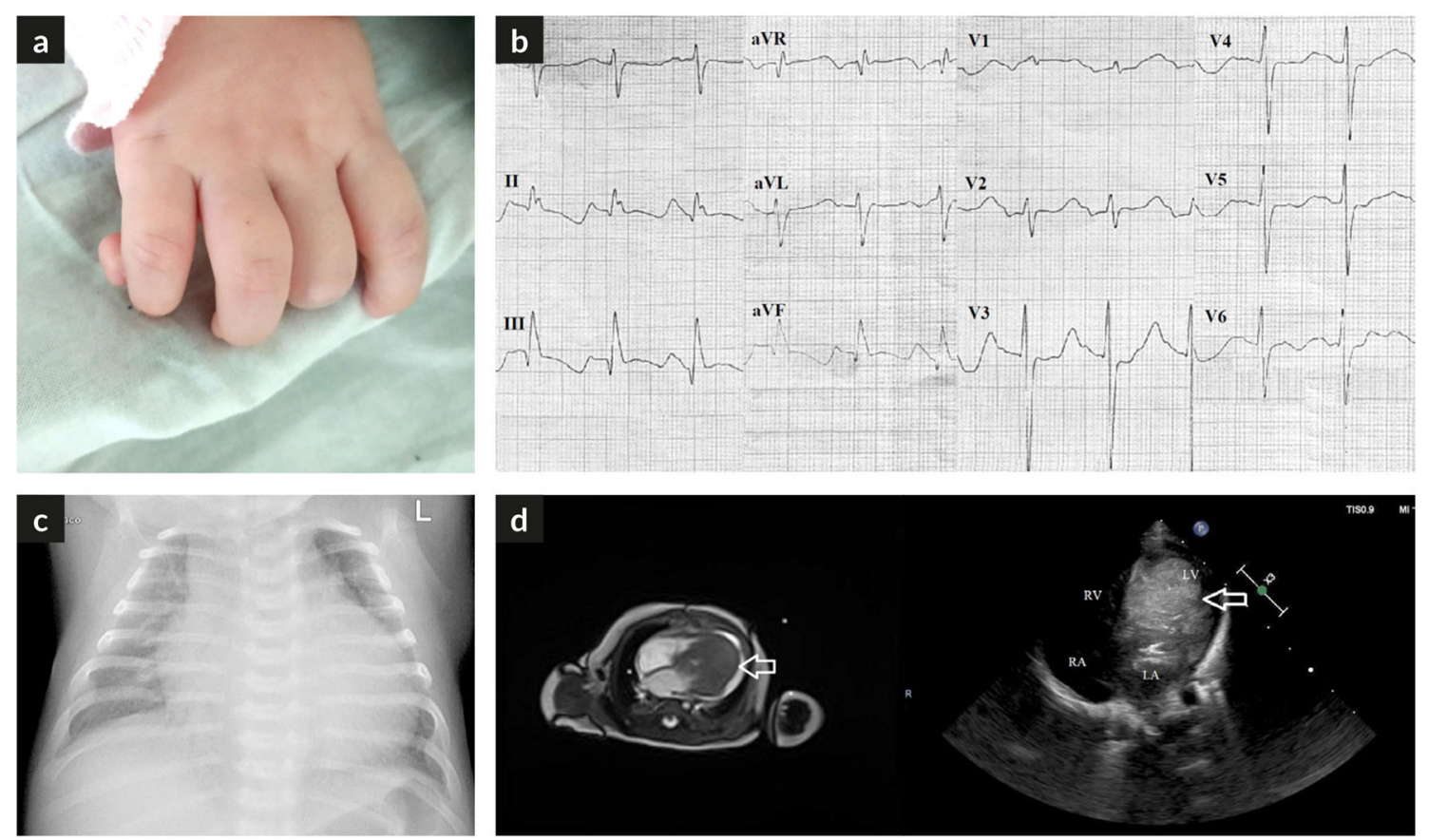

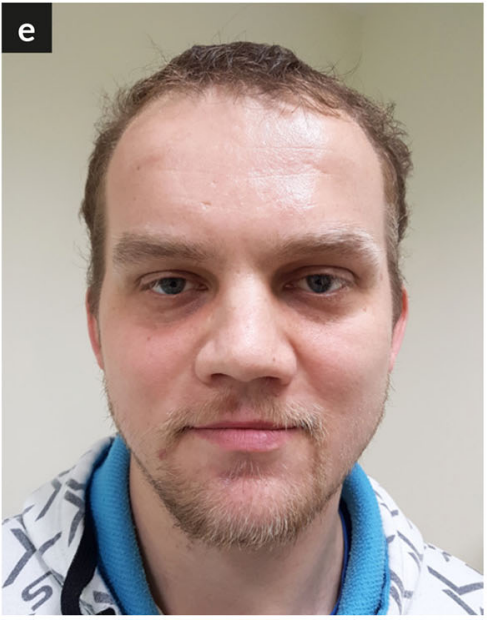

Fig. 1 a An additional phalanx of fifth finger in the proband. b The 12lead electrocardiogram of the proband demonstrating sinus rhythm with delayed intraventricular conduction and generalized repolarization abnormalities. c The anteroposterior projection chest radiograph

proband's grandparents' blood. Therefore, we concluded that this variant occurred de novo in the proband's father and was transmitted to the proband in an autosomal dominant manner of inheritance (Fig. 2). The p.(Leu923Pro) was absent in all queried databases, including in-house database of $>3000 \mathrm{ES}$ of Polish individuals, and was predicted to be damaging by in silico predictors using by Varsome (Kopanos et al. 2019).

\section{Discussion}

Neonatal cardiac tumors are predominantly rhabdomyomas. Multiple tumors suggest the diagnosis of tuberous sclerosis demonstrating cardiomegaly. d The transthoracic echocardiography, apical four-chamber view demonstrating a large bean-shaped tumor of the left ventricle. e Macrocephaly and frontal bossing in the father. $\mathbf{f}$ Pantomogram of the father showing maxillary cysts

while in case of single lesions, fibromas, myxomas, pericardial teratomas, and hemangiomas should be taken into account. Isolated cases constitute the majority of pediatric presentations of intracardiac tumors. In such individuals, both physical and intellectual developments remain unaffected. The management is restricted either to surgery in cases of ventricular outflow tract obstruction, embolism, and pulmonary/cardiac insufficiency or, most commonly, to monitoring cardiac function for a likely regression of the usually benign tumor. As the tumor shrinks in size, the foci of rest cells may create a background for rhythm disturbances (Mankad and Herrmann 2016). In the usually benign and slow-growing intracardiac tumors, sometimes, the parents have to be screened for 
Fig. 2 Results of ES analysis in the family

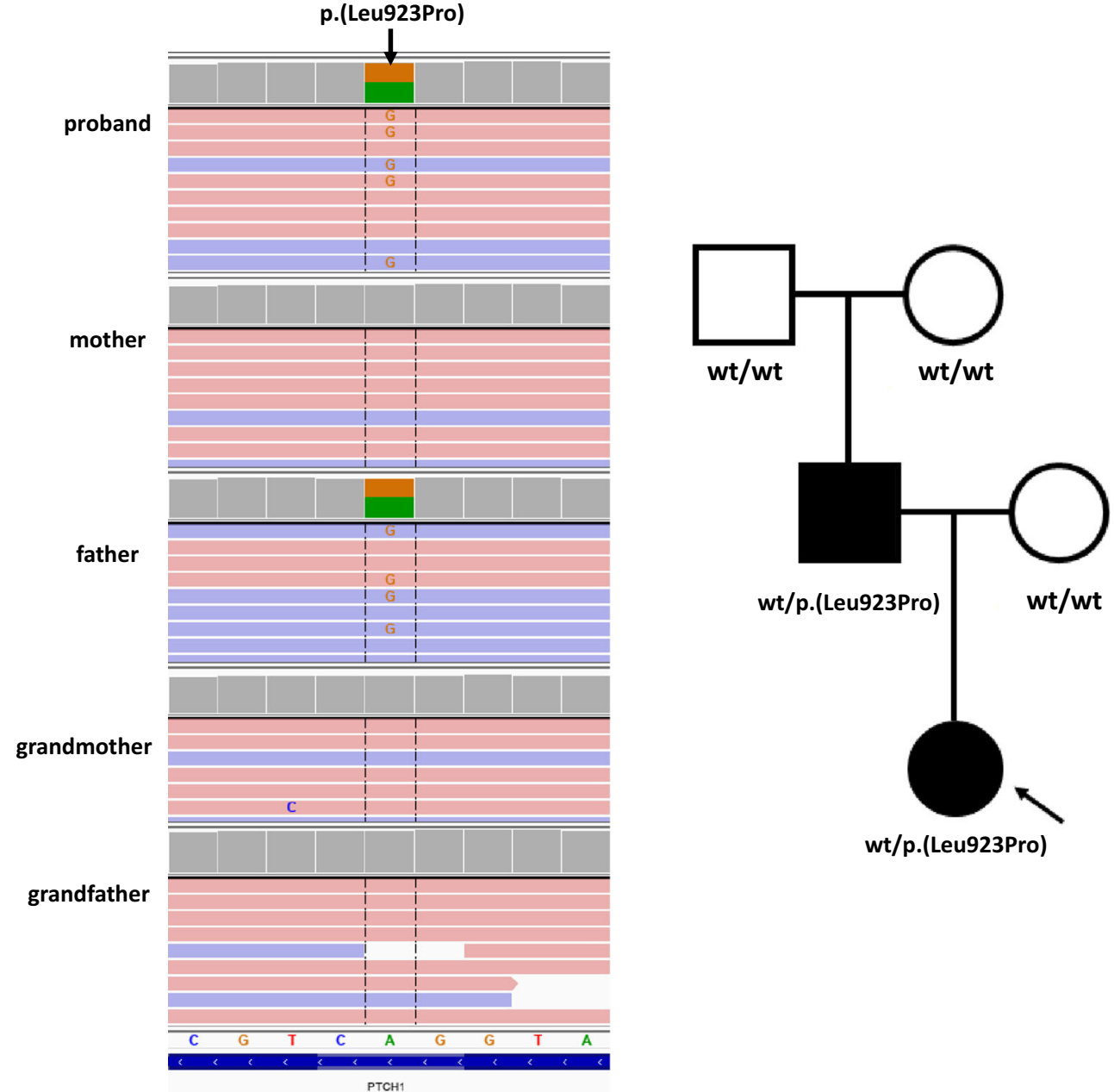

familial occurrences, e.g., familial myxoma syndrome. While rare, the genetic syndromes featuring intracardiac tumors present bigger challenges, both in terms of diagnosis and treatment. Our literature search on genetic conditions with intracardiac tumors revealed 10 fetal and pediatric entities that are shown in detail in Table 1. Apparently, there are distinct clinical features that prove helpful in establishing an early diagnosis of a certain genetic condition. Multiple tumors suggest an underlying tuberous sclerosis, especially in the setting of skin, kidney, and CNS typical findings. Cardiac tumors are also present as single occurrences in two other phakomatoses: Gorlin (NBCCS) syndrome and neurofibromatosis type 1 (NF1). In some conditions, establishing the pathological type of tumor may facilitate diagnosis. Myxoma at an early age, often multicentric and affecting any cardiac chamber, may imply the diagnosis of Carney complex in up to $23-32 \%$ of affected individuals (Vidaillet 1988; Bertherat et al. 2009). Cardiac lipoma suggests Cowden syndrome, while neurofibroma and paraganglioma point to NF1 and possible hereditary paraganglioma/pheochromocytoma syndromes, respectively. A critical implication of a syndromic intracardiac tumor diagnosis is a necessity for early-onset screening for extracardiac neoplasms in affected individuals. In 9 out of 10 conditions listed in Table 1, malignancies may arise as part of their clinical picture. Especially stringent guidelines for tumor screening have been established in BeckwithWiedemann syndrome characterized by bodily and internal organ overgrowth as well as embryonal tumors of liver and kidneys.

In our familial case, the final diagnosis was established by ES but combined clinical exam of the proband, and the father enabled inclusion of Gorlin syndrome in the differential diagnosis. The key symptoms present in the father were history of jaw cysts, macrocephaly, syndactyly, and polydactyly. Thus, this case best resembles Doede et al.'s description of an infant boy with macrocephaly and finger syndactyly and his mother with macrocephaly and facial fibromas (Doede et al. 2004). According to the authors, combined syndactyly of fingers and toes coupled with a cardiac tumor strongly suggests syndromic diagnoses. Indeed, the father of our proband had a complete syndactyly of the hands as well as unilateral polydactyly, and cardiac tumor with polydactyly was observed in the proband. Familial occurrence of Gorlin syndrome and the value of examining the probands' parents were underlined by 


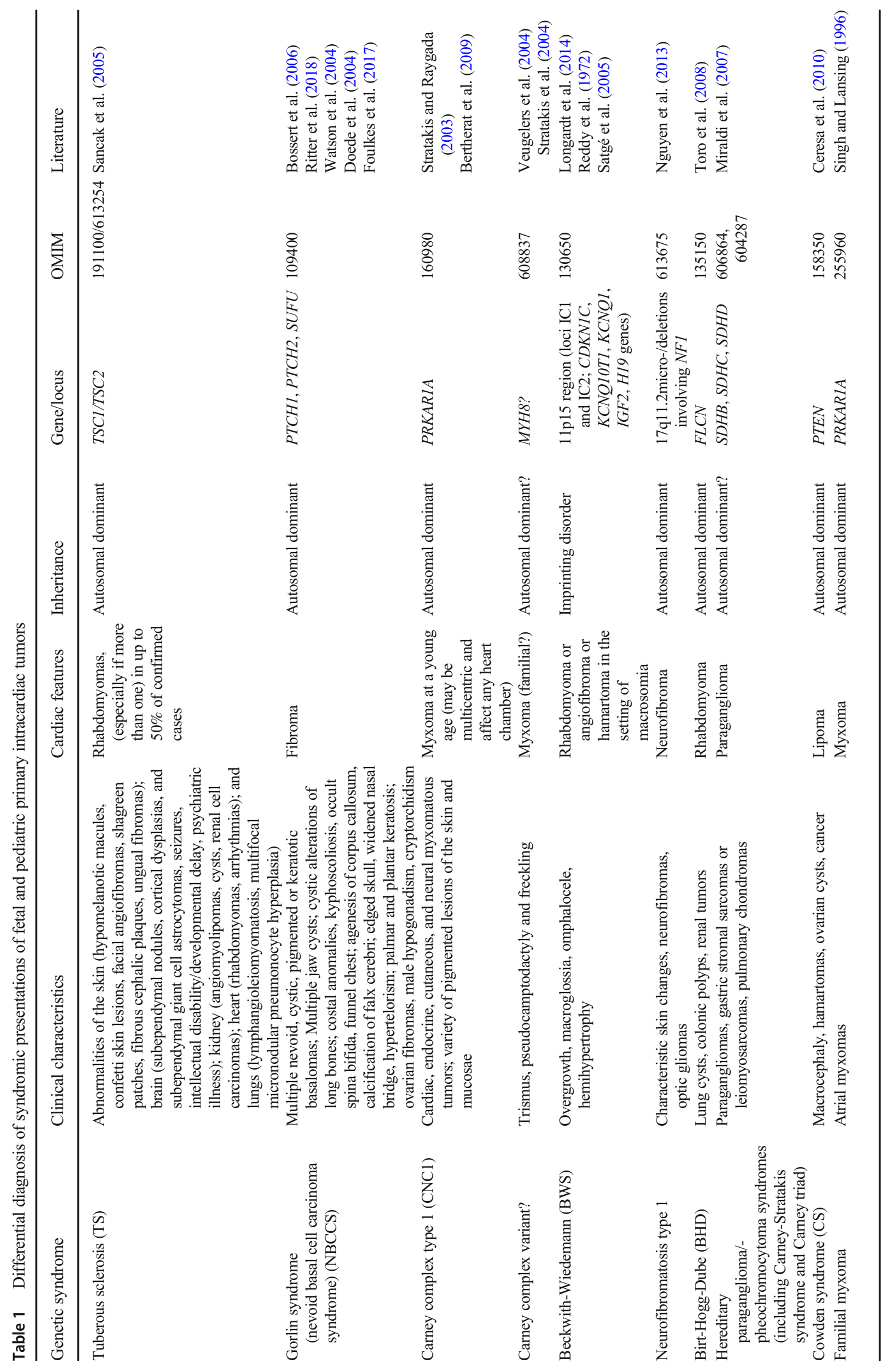


other authors. Ritter et al. reported jaw cysts in the father of an affected girl, and in Bossert et al.'s case, the mother of the proband had already been diagnosed with NBCCS (Ritter et al. 2018; Bossert et al. 2006).

In the presented infant girl, a therapeutic trial of sirolimus was initiated. This is based on an assumption that tuberous sclerosis (TS) is the most frequent syndromic presentation of cardiac tumors, and mTOR inhibitors are effective in treating CNS and kidney neoplasms of TS (Curatolo and Moavero 2012). Moreover, it may be difficult to exclude this condition in an early infantile period. However, the treatment was discontinued due to lack of effect. Unsurprisingly, the majority of tumor pathologies seen in NBCCS are fibromas, and there is no evidence of disrupted mTOR signaling in these tumors. Instead, loss of PTCH1 locus has been shown in cardiac fibroma tissue (Scanlan et al. 2008). Recently, in a mixed fibrous/myxoid type of gastric neoplasm called plexiform fibromyxoma, a link was established between Hedgehog signaling (Hh) and loss of PTCH1 (Banerjee et al. 2019). Treatment of the primary tumor cells with the Hh pathway inhibitor, sonidegib (LDE225, Novartis), resulted in dosedependent cell killing (Banerjee et al. 2019). This provides rationale for the future therapeutic trials of other tumors in the setting of PTCH1 loss, and it would be interesting to see how various types of tumors in Gorlin syndrome respond to the similar treatment.

In the described proband and her affected father, we have identified through ES a missense variant NM_000264.4:c.2768T $>\mathrm{C}$ in the PTCH1 gene creating a substitution p.(Leu923Pro). According to Varsome, most missense changes in PTCHI are of uncertain significance. However, this particular variant is absent from GnomAD or our in-house databases of variants, and in silico analyses are predictive of its pathogenicity. Moreover, the variant was excluded in healthy paternal grandparents of our proband. Thus far, somatic mutation p.Leu923Pro has only been found in childhood medulloblastomas as the Sonic Hedgehog (SHH) pathway is likely involved in progression of these tumors (Parsons et al. 2011; Iorgulescu et al. 2018). Medulloblastomas are part of the Gorlin syndrome where they may appear at ages 1-2 years, which is much earlier than expected in sporadic cases (Cowan et al. 1997). Thus, it may be reasonable to provide MRI brain imaging in such instances.

In summary, we present a familial case of Gorlin syndrome characterized by the presence of a rare intracardiac tumor in the proband. Clearly, the syndromic diagnosis enabled optimization of therapeutic management, and it may support introduction of specific prophylactic measures. Similar personalized management should be introduced once the diagnosis of any of the genetic syndromes presenting with primary intracardiac tumors and discussed here is reached.
Funding The study was supported by the National Science Centre (NCN) grants: $2017 / 27 / \mathrm{B} / \mathrm{NZ5} / 02223$ and by the Statutory Grant (SUB.E160.19.004)

\section{Compliance with ethical standards}

Conflict of interest The authors declare that they have no conflict of interest.

Informed consent Written informed consent for all the genetic studies performed in the patient and the parents was obtained from the patient's legal guardians (the parents).

Ethical approval All procedures performed in studies involving human participants were in accordance with the ethical standards of the Ethical Committee at the Warsaw Medical and with the 1964 Helsinki declaration and its later amendments or comparable ethical standards.

Open Access This article is licensed under a Creative Commons Attribution 4.0 International License, which permits use, sharing, adaptation, distribution and reproduction in any medium or format, as long as you give appropriate credit to the original author(s) and the source, provide a link to the Creative Commons licence, and indicate if changes were made. The images or other third party material in this article are included in the article's Creative Commons licence, unless indicated otherwise in a credit line to the material. If material is not included in the article's Creative Commons licence and your intended use is not permitted by statutory regulation or exceeds the permitted use, you will need to obtain permission directly from the copyright holder. To view a copy of this licence, visit http://creativecommons.org/licenses/by/4.0/.

\section{References}

Banerjee S, Corless CL, Miettinen MM et al (2019) Loss of the PTCH1 tumor suppressor defines a new subset of plexiform fibromyxoma. J Transl Med 17:246. https://doi.org/10.1186/s12967-019-1995-Z

Beghetti M, Gow RM, Haney I, Mawson J, Williams WG, Freedom RM (1997) Pediatric primary benign cardiac tumors: a 15-year review. Am Heart J 134(6):1107-1114. https://doi.org/10.1016/s00028703(97)70032-2

Bertherat J, Horvath A, Groussin L, Grabar S, Boikos S, Cazabat L, Libe R, Rene-Corail F, Stergiopoulos S, Bourdeau I, Bei T, Clauser E, Calender A, Kirschner LS, Bertagna X, Carney JA, Stratakis CA (2009) Mutations in regulatory subunit type 1A of cyclic adenosine 5'-monophosphate-dependent protein kinase (PRKAR1A): phenotype analysis in 353 patients and 80 different genotypes. J Clin Endocrinol Metab 94:2085-2091. https://doi.org/10.1210/jc.20082333

Bossert T, Walther T, Vondrys D, Gummert JF, Kostelka M, Mohr FW (2006) Cardiac fibroma as an inherited manifestation of nevoid basal-cell carcinoma syndrome. Tex Heart Inst J 33(1):88-90

Bree AF, Shah MR, BCNS Colloquium Group (2011) Consensus statement from the first international colloquium on basal cell nevus syndrome (BCNS). Am J Med Genet A 155A(9):2091-2097. https://doi.org/10.1002/ajmg.a.34128

Ceresa F, Calarco G, Franzì E, Patanè F (2010) Right atrial lipoma in patient with Cowden syndrome. Interact Cardiov Thorac Surg 11(6): 803-804. https://doi.org/10.1510/icvts.2010.245001

Cowan R, Hoban P, Kelsey A, Birch JM, Gattamaneni R, Evans DG (1997) The gene for the naevoid basal cell carcinoma syndrome acts 
as a tumour-suppressor gene in medulloblastoma. $\mathrm{Br} \mathrm{J}$ Cancer 76(2): 141-145. https://doi.org/10.1038/bjc.1997.354

Curatolo P, Moavero R (2012) mTOR inhibitors in tuberous sclerosis complex. Curr Neuropharmacol 10(4):404-415. https://doi.org/10. 2174/157015912804143595

Doede T, Seidel J, Riede FT et al (2004) Occult, life-threatening, cardial tumor in syndactylism in Gorlin Goltz syndrome. J Pediatr Surg 39(10):e17-e19. https://doi.org/10.1016/j.jpedsurg.2004.06.042

Foulkes WD, Kamihara J, Evans DGR, Brugières L, Bourdeaut F, Molenaar JJ, Walsh MF, Brodeur GM, Diller L (2017) Cancer surveillance in Gorlin syndrome and Rhabdoid tumor predisposition syndrome. Clin Cancer Res 23(12):e62-e67. https://doi.org/10. 1158/1078-0432.CCR-17-0595

Gorlin RJ (1987) Nevoid basal-cell carcinoma syndrome. Medicine 66: 98-113. https://doi.org/10.1097/00005792-198703000-00002

Gorlin RJ (2004) Nevoid basal cell carcinoma (Gorlin) syndrome. Genet Med 6(6):530-539. https://doi.org/10.1097/01.gim.0000144188. $15902 . c 4$

Holley DG, Martin GR, Brenner JI (1995) Diagnosis and management of fetal cardiac tumors: a multicenter experience and review of published reports. J Am Coll Cardiol 26:516-520. https://doi.org/10. 1016/0735-1097(95)80031-B

Iorgulescu JB, Van Ziffle J, Stevers M et al (2018) Deep sequencing of WNT-activated medulloblastomas reveals secondary SHH pathway activation. Acta Neuropathol 135(4):635-638. https://doi.org/10. 1007/s00401-018-1819-x

Johnson RL, Rothman AL, Xie J, Goodrich LV, Bare JW, Bonifas JM, Quinn EH, Myers RM, Cox DR, Epstein EH Jr, Scott MP (1996) Human homolog of patched, a candidate gene for the basal cell nevus syndrome. Science 272:1668-1671. https://doi.org/10.1126/ science. 272.5268 .1668

Kopanos C, Tsiolkas V, Kouris A et al (2019) VarSome: the human genomic variant search engine. Bioinformatics. 35(11):1978-1980. https://doi.org/10.1093/bioinformatics/bty897

Lin CW, Zeng XL, Jiang SH et al (2013) Role of the NT-proBNP level in the diagnosis of pediatric heart failure and investigation of novel combined diagnostic criteria. Exp Ther Med 6(4):995-999. https:// doi.org/10.3892/etm.2013.1250

Linnemeier L, Benneyworth BD, Turrentine M, Rodefeld M, Brown J (2015) Pediatric cardiac tumors: a 45-year, single-institution review. World J Pediatr Congenit Heart Surg 6:215-219. https://doi.org/10. $1177 / 2150135114563938$

Longardt AC, Nonnenmacher A, Graul-Neumann L, Opgen-Rhein B, Henrich W, Bührer C, Hüseman D (2014) Fetal intracardiac rhabdomyoma in beckwith-wiedemann syndrome. J Clin Ultrasound 42(9):569-573. https://doi.org/10.1002/jcu.22164

Mankad R, Herrmann J (2016) Cardiac tumors: echo assessment. Echo Res Pract 3(4):R65-R77. https://doi.org/10.1530/ERP-16-0035

Miraldi F, Taffon C, Toscano M, Barretta A. (2007) Black cardiac paraganglioma in a multiple paraganglioma syndrome

Nguyen R, Mir TS, Kluwe L et al (2013) Cardiac characterization of 16 patients with large NF1 gene deletions. Clin Genet 84(4):344-349. https://doi.org/10.1111/cge.12072

Parsons DW, Li M, Zhang X et al (2011) The genetic landscape of the childhood cancer medulloblastoma. Science. 331(6016):435-439. https://doi.org/10.1126/science.1198056

Reddy JK, Schimke RN, Chang CH et al (1972) Beckwith-Wiedemann syndrome. Wilms' tumor, cardiac hamartoma, persistent visceromegaly, and glomeruloneogenesis in a 2-year-old boy. Arch Pathol 94:523

Ritter AL, Granquist EJ, Iyer VR, Izumi K (2018) Cardiac fibroma with ventricular tachycardia: an unusual clinical presentation of nevoid basal cell carcinoma syndrome. Mol Syndromol 9(4):219-223. https://doi.org/10.1159/000489056

Rydzanicz M, Wachowska M, Cook EC et al (2019) Novel calcineurin A (PPP3CA) variant associated with epilepsy, constitutive enzyme activation and downregulation of protein expression. Eur J Hum Genet 27(1):61-69. https://doi.org/10.1038/s41431-018-0254-8

Sancak O, Nellist M, Goedbloed M et al (2005) Mutational analysis of the TSC1 and TSC2 genes in a diagnostic setting: genotype-phenotype correlations and comparison of diagnostic DNA techniques in tuberous sclerosis complex. Eur J Hum Genet 13(6):731-741. https://doi. org/10.1038/sj.ejhg.5201402

Satgé D, Vidalo E, Desfarges F, de Geeter B (2005) A third case of cardiac neoplasm in a fetus with Beckwith-Wiedemann syndrome: epicardial angiofibroma. Fetal Diagn Ther 20(1):44-47. https://doi. org/10.1159/000081368

Scanlan D, Radio SJ, Nelson M et al (2008) Loss of the PTCH1 gene locus in cardiac fibroma. Cardiovasc Pathol 17(2):93-97. https://doi. org/10.1016/j.carpath.2007.08.001

Singh SD, Lansing AM (1996) Familial cardiac myxoma - a comprehensive review of reported cases. J Ky Med Assoc 94(3):96-104

Stratakis CA, Raygada M. Carney Complex. 2003 Feb 5 [Updated 2018 Aug 16]. In: Adam MP, Ardinger HH, Pagon RA, et al. editors. GeneReviews ${ }^{\circledR}$ [Internet]. Seattle (WA): University of Washington, Seattle; 1993-2020. Available from: https://www. ncbi.nlm.nih.gov/books/NBK1286/

Stratakis CA, Bertherat J, Carney JA (2004) Mutation of perinatal myosin heavy chain. N Engl J Med 351(24):2556-2558. https://doi.org/10. 1056/NEJM200412093512420

Toro JR, Wei MH, Glenn GM et al (2008) BHD mutations, clinical and molecular genetic investigations of Birt-Hogg-Dubé syndrome: a new series of 50 families and a review of published reports. J Med Genet 45(6):321-331. https://doi.org/10.1136/jmg.2007.054304

Tzani A, Doulamis IP, Mylonas KS, Avgerinos DV, Nasioudis D (2017) Cardiac tumors in pediatric patients: a systematic review. World $\mathrm{J}$ Pediatr Congenit Heart Surg 8(5):624-632. https://doi.org/10.1177/ 2150135117723904

Uzun O, Wilson DG, Vujanic GM, Parsons JM, De Giovanni JV (2007) Cardiac tumours in children. Orphanet J Rare Dis 2:11. https://doi. org/10.1186/1750-1172-2-11

Veugelers M, Bressan M, McDermott DA et al (2004) Mutation of perinatal myosin heavy chain associated with a Carney complex variant. N Engl J Med 351(5):460-469. https://doi.org/10.1056/ NEJMoa040584

Vidaillet HJ Jr (1988) Cardiac tumors associated with hereditary syndromes. Am J Cardiol 61(15):1355. https://doi.org/10.1016/00029149(88)91186-1

Watson J, Depasquale K, Ghaderi M, Zwillenberg S (2004) Nevoid basal cell carcinoma syndrome and fetal rhabdomyoma: a case study. Ear Nose Throat J 83:716-718

Publisher's note Springer Nature remains neutral with regard to jurisdictional claims in published maps and institutional affiliations. 